\title{
Extending Telomere Length with a Multivitamin: A Pilot Study
}

Eugene J Bruno ${ }^{1}$, Graham D Simpson ${ }^{2}$ and Robert L Martin ${ }^{2}$

${ }^{1}$ Huntington College of Health Sciences, Knoxville, TN 37918, USA

${ }^{2}$ West-Martin Longevity, USA

*Corresponding author: Eugene J Bruno, MS, MHS, RH (AHG), Professor of Nutraceutical Science and Provost, Huntington College of Health Sciences, Knoxville, TN 37918, USA, E-mail: gbruno@hchs.edu

Received date: November 03, 2017; Accepted date: November 09, 2017; Published date: November 15, 2017

Copyright: (c) 2017 Bruno EJ, et al. This is an open-access article distributed under the terms of the Creative Commons Attribution License, which permits unrestricted use, distribution, and reproduction in any medium, provided the original author and source are credited.

\begin{abstract}
Context: Although telomeres are "sacrificial" DNA without any necessary genetic content, each time a cell divides, telomeres get shorter. When they decrease to a critical length, cell division ceases and cells becomes inactive or "senescent" or die. This process is associated with aging. To some extent, the process of telomere shortening is slowed by the enzyme telomerase, whose purpose it is to add telomere length to DNA. Certain nutraceuticals have been shown to activate telomerase, and extend telomere length. While this will not make cells immortal, it may extend their lifespan.
\end{abstract}

Objectives: The study intended to examine the effectiveness of a multivitamin formulated to extend telomere length, and ascertain the viability of conducting a larger, randomized, controlled trial in the future.

Design: The study a 90-day, open-label pilot.

Participants: Generally healthy men and women older than 18 years.

Intervention: All subjects received a 90-day supply of the multivitamin, and were instructed to take one table, three times daily with meals.

Outcome measures: The endpoint was absolute telomere length, measured with the quantitative real-time polymerase chain reaction (qPCR) method, using a DNA sample from a buccal (inner-cheek) swab of each subject.

Results: 10 subjects completed the protocol. 8 of the 10 had notable increases in telomere length. The mean increase in telomere length for all subjects was $55.86 \%$.

Conclusions: The current pilot trial demonstrated the efficacy of the multivitamin in lengthening the telomeres. These findings suggest that is worthwhile to conduct a larger, randomized, controlled trial to measure the telomere lengthening effects of the multivitamin formula.

Keywords: Nutraceuticals; Genetic; Multivitamin; Buccal; Telomeres

\section{Introduction}

There are multiple theories on aging which may be classified under the general headings of programmed aging or unprogrammed aging. Programmed aging may be described as aging resulting from genetically programmed factors. Unprogrammed aging may be described as aging resulting from molecular damage to normal body cells and molecules. According to Spence [1], a compelling argument can be made for some manner of programmed aging since aging begins at birth and each species seems to have its own average lifespan. The telomere theory of aging falls into this classi ication.

As cells age, they lose a certain number of base pairs of DNA, known as telomeres, from the end of each chromosome every time cell division takes place. Although the telomeres are "sacrificial" DNA without any necessary genetic content, there is still a problem. When these telomeres have decreased to a critical length, cell division ceases; although cell senescence may continue for a time [2]. This finite ability to replicate is known as the "Hayflick limit," and has been seen in normal cultured human and animal cells [3]. Fibroblast cells taken from adults would only divide about 20 times in vitro, although this limit is rarely, if ever, reached in the body [1]. Summarily, each time a cell divides, telomeres get shorter. When they get too short, the cell can no longer divide and becomes inactive or "senescent" or dies. This process is associated with aging [2].

To some extent, the process of telomere shortening is slowed by the enzyme telomerase, whose purpose it is to add telomere length to DNA [2]. Telomerase is found in some cells (e.g., germ cells and stem cells), which must divide continually to perform their functions. By promoting telomerase activity, it is possible to increase telomere length and consequently extend the period of time that cellular division can take place. While this will not make cells immortal, it may extend their lifespan [3].

Of particular interest is the fact that certain nutraceuticals have been shown to activate telomerase, and extend telomere length. One 
Page 2 of 3

such nutraceutical is vitamin $\mathrm{D}$. In a double blind, randomized and placebo-controlled clinical trial [4], Zhu et al. examined the effect of vitamin D supplementation on telomerase activity in 37 overweight African American adults. Subjects received a placebo or the equivalent of 2000 IU oral vitamin D3 supplementation daily for 16 weeks. Results showed that in the vitamin $\mathrm{D}$ group, telomerase activity significantly increased by $19.2 \% \quad(\mathrm{P}<0.0001)$. The significance persisted after controlling for age, sex and body mass index. Telomerase activity in the placebo group did not change.

This is consistent with research [5] by Richards et al. which showed that higher serum vitamin D concentrations in 2160 women were positively significantly associated with leukocyte telomere length $(\mathrm{P}=0.001)$, and the difference in telomere length between those with the highest and lowest vitamin D intake was 107 base pairs, which is equivalent to 5 years of telomeric aging. Similarly, human research has demonstrated longer telomere length in association with higher consumption of tea [6], lutein, zeaxanthin, and vitamin C [7], as well as several other vitamins and minerals [8].

As a result of these, and other studies demonstrating the telomerase activating and/or telomere lengthening effects of nutraceuticals, a multivitamin was formulated to extend telomere length (TeloVite, West-Martin Longevity) and a pilot study was conducted to examine the efficacy of the formulation in extending telomere length, and ascertain the viability of conducting a larger, randomized, controlled trial in the future.

\section{Materials and Methods}

\section{Participants}

The 90-day study was an open-label pilot. Generally healthy men and women older than 18 years were deemed eligible for participation. Subjects were recruited between February 1, 2013, and June 1, 2013, from a video solicitation on the website of West-Martin Longevity. All eligible patients were screened by the principal investigator. All volunteers had to have stable health (i.e., no hospitalizations, medical procedures, or changes in medications for at least $30 \mathrm{~d}$ prior to enrollment). Exclusion criteria included (1) having a life expectancy of less than 6 months, (2) being pregnant or currently breastfeeding, (3) being unwilling or unable to complete 90-days of supplementation with Telovite, or (4) currently using any other dietary supplement.

\section{Procedures}

After written informed consent was obtained, baseline assessments were completed, including each participant's (1) demographics; (2) medical history; (3) current medications and dosages; (4) height; (5) weight; and (6) BMI. Subjects received individualized instructions regarding the use of Telovite. DNA samples from buccal swabs were obtained at baseline, and at day 90 .

\section{Intervention}

All subjects received a 90-day supply of Telovite (Table 1), and were instructed to take one table, three times daily with meals. They were also instructed not to change their current dietary practices or exercise routine.

\section{Amount Per 3 Tablets:}

Vitamin A (as acetate, beta-carotene)

$5000 \mathrm{IU}$

\begin{tabular}{|c|c|}
\hline Vitamin C (as ascorbic acid, calcium ascorbate) & $400 \mathrm{mg}$ \\
\hline Vitamin D3 (as cholecalciferol) & $2000 \mathrm{IU}$ \\
\hline Vitamin E (as d-alpha tocopheryl succinate and mixed tocopherols) & $30 \mathrm{IU}$ \\
\hline Vitamin K2 (as MK7) & $45 \mathrm{mcg}$ \\
\hline Vitamin B1 (as thiamin $\mathrm{HCl}$ ) & $50 \mathrm{mg}$ \\
\hline Vitamin B2 (riboflavin) & $50 \mathrm{mg}$ \\
\hline Niacin (as Niacinamide) & $100 \mathrm{mg}$ \\
\hline Vitamin $\mathrm{B} 6$ (as pyridoxine $\mathrm{HCl}$ ) & $50 \mathrm{mg}$ \\
\hline Folic acid & $\begin{array}{l}400 \\
\mathrm{mcg}\end{array}$ \\
\hline Vitamin B12 (as cyanocobalamin) & $\begin{array}{l}100 \\
\mathrm{mcg}\end{array}$ \\
\hline Biotin & $\begin{array}{l}300 \\
\mathrm{mcg}\end{array}$ \\
\hline Pantothenic Acid (as d-calcium pantothenate) & $50 \mathrm{mg}$ \\
\hline $\begin{array}{l}\text { Calcium (as carbonate, dibasic calcium phosphate, citrate, } \\
\text { ascorbate) }\end{array}$ & $220 \mathrm{mg}$ \\
\hline Phosphorus (as dibasic calcium phosphate) & $48 \mathrm{mg}$ \\
\hline lodine (potassium iodide, kelp) & $\begin{array}{l}150 \\
\mathrm{mcg}\end{array}$ \\
\hline Magnesium (as oxide, citrate) & $100 \mathrm{mg}$ \\
\hline Zinc (as amino acid chelates) & $15 \mathrm{mg}$ \\
\hline Selenium (as selenomethionine) & $70 \mathrm{mcg}$ \\
\hline Copper (as amino acid chelates) & $2 \mathrm{mg}$ \\
\hline Manganese (as amino acid chelates) & $2 \mathrm{mcg}$ \\
\hline Chromium (as polynicotinate) & $\begin{array}{l}150 \\
\mathrm{mcg}\end{array}$ \\
\hline Molybdenum (as sodium molybdate) & $5 \mathrm{mcg}$ \\
\hline Chloride (as potassium chloride) & $72 \mathrm{mcg}$ \\
\hline Potassium (as potassium chloride) & $80 \mathrm{mg}$ \\
\hline Green Tea leaf extract (Standardized to $90 \%$ polyphenols) & $250 \mathrm{mg}$ \\
\hline Chlorella (Chlorella vulgaris) & $100 \mathrm{mg}$ \\
\hline L-Carnosine & $50 \mathrm{mg}$ \\
\hline Resveratrol (providing $30 \mathrm{mg}$ trans-resveratrol) & $60 \mathrm{mg}$ \\
\hline Grape seed extract $(85-95 \%$ OPC) & $30 \mathrm{mg}$ \\
\hline Choline bitartrate & $25 \mathrm{mg}$ \\
\hline Inositol & $25 \mathrm{mg}$ \\
\hline Silicon (as sodium metasilicate) & $2 \mathrm{mg}$ \\
\hline Lycopene & $\begin{array}{l}300 \\
\mathrm{mcg}\end{array}$ \\
\hline Lutein & $\begin{array}{l}250 \\
\mathrm{mcg}\end{array}$ \\
\hline
\end{tabular}


Page 3 of 3

\begin{tabular}{|l|l|}
\hline Zeaxanthin & $50 \mathrm{mcg}$ \\
\hline Boron & $\begin{array}{l}150 \\
\mathrm{mcg}\end{array}$ \\
\hline Vanadium (as vanadyl sulfate) & $10 \mathrm{mcg}$ \\
\hline Nickel (as nickel sulfate) & $5 \mathrm{mcg}$ \\
\hline
\end{tabular}

Table 1: Telovite Composition.

\section{Outcomes}

The outcome was absolute telomere length, measured with a simple and reproducible, quantitative real-time polymerase chain reaction (qPCR) method described by O'Callaghan and Fenech, using a DNA sample from a buccal (inner-cheek) swab of each subject [9]. The qPCR analysis was conducted at Titanovo Labs (North Carolina).

Fifteen subjects were recruited for the pilot study. Due to attrition and non-compliance, ten subjects completed the protocol and were included in the results. Results were that 8 out of the 10 subjects had notable increases in telomere length, whereas the remaining two subjects had a decrease in telomere length. The reason for the decrease in telomere length in the 2 subjects is unclear (Table 2).

\begin{tabular}{|l|l|l|l|l|l|l|}
\hline Subject & Sex & Age & $\begin{array}{l}\text { Telomere } \\
\text { Length- } \\
\text { Day 0 }\end{array}$ & $\begin{array}{l}\text { Telomere } \\
\text { Length- } \\
\text { Day 90 }\end{array}$ & $\begin{array}{l}\text { Change in } \\
\text { Telomere } \\
\text { Length }\end{array}$ & $\begin{array}{l}\% \\
\text { Change }\end{array}$ \\
\hline 1 & M & 50 & 0.9 & 1.8 & 0.9 & 100 \\
\hline 2 & M & 53 & 1.3 & 2 & 0.7 & 52.38 \\
\hline 3 & M & 44 & 1 & 1.7 & 0.7 & 67.6 \\
\hline 4 & M & 51 & 1.1 & 1.8 & 0.7 & 63.45 \\
\hline 5 & F & 62 & 0.8 & 1.6 & 0.8 & 100 \\
\hline 6 & F & 69 & 1.1 & 1.5 & 0.4 & 35 \\
\hline 7 & F & 72 & 0.9 & 1.8 & 0.9 & 99.11 \\
\hline 8 & M & 71 & 0.8 & 1.6 & 0.8 & 100.5 \\
\hline 9 & M & 49 & 1.5 & 1.1 & -0.4 & -26.13 \\
\hline 10 & F & 49 & 0.9 & 0.6 & -0.3 & -33.33 \\
\hline
\end{tabular}

Table 2: Change in Telomere Length from 90 Days Supplementation with Telovite.

The mean increase in telomere length for the eight subjects was $77.26 \%$. When all 10 subjects are included, the mean increase in telomere length was $55.86 \%$.

\section{Discussion}

The purpose of this pilot study was to examine the efficacy of the Telovite formulation in extending telomere length, and ascertain the viability of conducting a larger, randomized, controlled trial in the future. While there were an insufficient number of subjects to adequately power the study and calculate statistical significance, the results of this open-label pilot study are promising, and indicate that 90 days of supplementation with Telovite was effective in lengthening telomeres in the majority of subjects tested.

\section{Conclusion}

The current pilot trial demonstrated the efficacy of Telovite in lengthening the telomeres of 8 out of the 10 subjects. These findings suggest that is worthwhile to conduct a larger, randomized, controlled trial to measure the telomere lengthening effects of Telovite, giving further consideration to the reasons behind the lack of telomere lengthening in the minority of subjects.

\section{Acknowledgement}

This study was made possible by a grant from West-Martin Longevity.

\section{References}

1. Spence AP (1999) Biology of Human Aging. 2nd edn. Prentice Hall, Upper Saddle River, NJ.

2. Bryan TM, Reddel RR (1996) Telomerase, Immortality and Cancer. Today's Life Science 8: 26-28.

3. Hayflick L (1985) Theories of biological aging: Programmed Aging. Experimental Gerontology 20: 145-159.

4. Zhu H, Guo D, Li K, Pedersen-White J, Stallmann-Jorgensen IS, et al. (2012) Increased telomerase activity and vitamin D supplementation in overweight African Americans. Int J Obes (Lond) 36: 805-809.

5. Richards JB, Valdes AM, Gardner JP, Paximadas D, Kimura M, et al. (2007) Higher serum vitamin D concentrations are associated with longer leukocyte telomere length in women. Am J Clin Nutr 86: 1420-1425.

6. Chan R, Woo J, Suen E, Leung J, Tang N (2010) Chinese tea consumption is associated with longer telomere length in elderly Chinese men. $\mathrm{Br} \mathrm{J}$ Nutr 103: 107-113.

7. Sen A, Marsche G, Freudenberger P, Schallert M, Toeglhofer AM, et al. (2014) Association between higher plasma lutein, zeaxanthin, and vitamin $\mathrm{C}$ concentrations and longer telomere length: results of the Austrian Stroke Prevention Study. J Am Geriatr Soc 62: 222-229.

8. Xu Q, Parks CG, DeRoo LA, Cawthon RM, Sandler DP, et al. (2009) Multivitamin use and telomere length in women. Am J Clin Nutr 89: 1857-1863.

9. O'Callaghan NJ, Fenech M (2011) A quantitative PCR method for measuring absolute telomere length. Biol Proced Online 13: 3 . 